\title{
CEPAL Review
}

\author{
Executive Secretary \\ Norberto González
}

Deputy Executive Secretary for

Economic and Social Development

Gert Rosenthal

Deputy Executive Secretary for

Co-operation and Support Services

Robert T. Brown

Technical Secretary

Adolfo Gurrieri

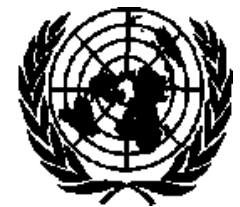

UNITED NATIONS

ECONOMIC COMMISSION FOR LATIN AMERICA AND THE CARIBBEAN 


\section{EPAL}

Review

Santiago, Chile

Number 29

\section{CONTENTS}

Note

Raúl Prebisch 1901-1986. Aníbal Pinto

Address delivered by Dr. Raúl Prebisch at the twenty-first session of ECAC

Latin American youth between development and crisis. Germán Rama

Youth in Argentina: between the legacy of the past and the construction of the future. Cecilia Braslavsky

Youth in Brazil: old assumptions and new approaches. Felicia Reicher Madeira

The missing future: Colombian youth. Rodrigo Parra Sandoval

Chilean youth and social exclusion. Javier Martinez and Eduardo Valenzuela

The political radicalization of working-class youth in Peru. Julio Cotler

Youth and unemployment in Montevideo. Ruben Kaztman

Youth in the English-speaking Caribbean: the high cost of dependent development. Meryl

James-Bryan

Thinking about youth. Carlos Martinez Moreno

Working-class youth and anomy. Javier Martinez and Eduardo Valenzuela

Youth as a social movement in Latin America. Enzo Faletto

University youth as social protagonist in Latin America. Henry Kirsch 


\section{Chilean youth and social exclusion}

\section{Javier Martinez Eduardo Valenzuela*}

Young people in Chile have seen a sharp increase in their participation and their chances of involvement in the social roles shaped during the postwar period of expansion. The rapid urbanization, the great expansion of education systems, the extension of the political rights of citizenship, and the growing absorption of skilled and unskilled manpower by the modern production and services sectors were some of the factors which mobilized young people and turned them into some of the most committed agents of development and modernization; since development and modernization were also the axes of consensus among almost all the social and political protagonists, youth became, almost inadvertently, one of the central agents in the system. One of the most graphic instances of this was the remarkable political and cultural influence exercised by the student movements towards the end of the 1960s.

However, a new phenomenon has emerged in Chile's social development in the past decade - social exclusion, which affects the structure of society itself, and thus all the social categories and agents, but whose deepest and broadest effects are probably on youth. "Exclusion" means the process of structural change by which various social groups which in the immediate past had occupied stable institutionalized positions in the social system, or could have firm expectations of places in it, have been dismissed from these positions or find their access to them persistently blocked.

For this very reason youth was one of the main victims of the crisis, redefinition and distortion of the modernization processes: it can be said that in the past decade this exclusion has affected Chilean young people almost to the same extent that they had attained central positions in the system in the two previous decades.

'Consultants to [iCLACs Social Development Division.

\section{Crisis of growth and economic participation}

Young people in Chile today represent an extensive social sector with a high level of education - almost three times higher than the average level of their parents' generation - and with already remote migratory antecedents; they would seem to be in the optimum position to take charge of the complex tasks required by urban life, social modernization and political and economic development. In fact, one of the main goals of the expansion of the school system over the past quarter of a century was to involve youth in the development process.

It cannot be denied that the education system"" showed remarkable efficiency in absorbing the whole of the young generation, leaving many elitist barriers in its wake. The latest census figures show clearly the decline in the rates of economic participation by young people due to the expansion of education: the labour supply of young people aged 15 to 19 fell nationally from $42.2 \%$ in I960 to $30.7 \%$ in 1970 , and it fell in absolute terms as well. This drop was sharpest in the urban areas (from $38.8 \%$ to $27.2 \%$ ), the very areas which benefitted most from the growth in education; and it was much sharper for men, whose rate fell from $61.7 \%$ to $45.3 \%$ over the period. Employment of young people aged 20 to 24 also declined between these dates, although certainly to a lesser extent. In this case the drop in the rate of participation was found only in the urban areas and again mainly among men (who benefitted most from the expansion of higher-education opportunities).

However, for education to have been able to discharge effectively the role assigned to it, there would have to have been, in step with the expansion of schooling, a comparable expansion of the modern sectors of production, trade and services, which were the ones expected to absorb the better-qualified labour. When this did not happen, there was a resumption of the declining trend in the proportion of youth in the labour force. In fact, the projections indicated that the proportion of young people aged 14 to 19 was to 
continue declining in the coming decades as a result of the extension of schooling, while the proportion of active persons in the 20-24 age group was to increase only as a result of a larger entry of women into the labour markets. But, despite the expansion of education, the pressure of young people on the labour markets did not decline by the expected amounts.

Several studies have referred to the irregularity of Chile's economic growth as an explanation of the behaviour of the rate of participation. Cáceres (1981) pointed out for example that the economic activity of the 15-19 age group fell sharply in the years of greatest expansion of education (1968-1973), but then increased during the acute recession of 1975-
1976. Rosales (1979) had earlier studied the cyclical trend in the rate of secondary participation of women, discovering that women's participation in the bottom strata fell during the 1975 crisis (especially in the over-20 and under-45 age groups), while in the top strata this participation reached its lowest level for the whole of the period studied (1957-1977). This fact also helps to explain why the expected increase in women's participation has not occurred, at least not so far.

This thesis emphasizes the cyclical behaviour of the work participation of the secondary labour force: in conditions of economic crisis (with high levels of unemployment and a decline in personal

Table 1

CHILE: YOUNG POPULATION AGED 15-24, BY SCHOOL ATTENDANCE AND
ECONOMIC ACTIVITY, I960, 1970, 1980

\begin{tabular}{|c|c|c|c|c|c|}
\hline & \multirow[b]{2}{*}{ Years } & \multicolumn{2}{|c|}{ Attending } & \multicolumn{2}{|c|}{ Not attending } \\
\hline & & $\begin{array}{l}\text { Thousands } \\
\text { of persons }\end{array}$ & Percentages & $\begin{array}{l}\text { Thousands } \\
\text { of persons }\end{array}$ & Percentages \\
\hline $\begin{array}{l}\text { Aged } 15 \text { - } \\
\text { Active }\end{array}$ & $\begin{array}{l}1960 \\
1970 \\
1980\end{array}$ & $\begin{array}{r}12.2 \\
28.2 \\
116.1\end{array}$ & $\begin{array}{l}0.9 \\
1.7 \\
4.8\end{array}$ & $\begin{array}{l}663.6 \\
663.4 \\
824.5\end{array}$ & $\begin{array}{l}50.2 \\
39.9 \\
33.8\end{array}$ \\
\hline Inactive & $\begin{array}{l}1960 \\
1970 \\
1980\end{array}$ & $\begin{array}{r}276.8 \\
502.0 \\
1040.1\end{array}$ & $\begin{array}{l}20.9 \\
30.2 \\
42.6\end{array}$ & $\begin{array}{l}369.8 \\
468.6 \\
460.0\end{array}$ & $\begin{array}{l}28.0 \\
28.2 \\
18.9\end{array}$ \\
\hline $\begin{array}{l}\text { Aged } 15- \\
\text { Active }\end{array}$ & $\begin{array}{l}1960 \\
1970 \\
1980\end{array}$ & $\begin{array}{r}8.1 \\
12.5 \\
61.7\end{array}$ & $\begin{array}{l}1.1 \\
1.4 \\
4.5\end{array}$ & $\begin{array}{l}303.8 \\
253.2 \\
239.7\end{array}$ & $\begin{array}{l}41.8 \\
27.9 \\
17.6\end{array}$ \\
\hline Inactive & $\begin{array}{l}1960 \\
1970 \\
1980\end{array}$ & $\begin{array}{l}243.2 \\
426.2 \\
876.0\end{array}$ & $\begin{array}{l}33.5 \\
46.9 \\
64.1\end{array}$ & $\begin{array}{l}171.1 \\
217.3 \\
188.7\end{array}$ & $\begin{array}{l}23.6 \\
23.9 \\
13.8\end{array}$ \\
\hline $\begin{array}{l}\text { Aged } 20 \text { - } \\
\text { Active }\end{array}$ & $\begin{array}{l}1960 \\
1970 \\
1980\end{array}$ & $\begin{array}{r}4.1 \\
15.7 \\
54.5\end{array}$ & $\begin{array}{l}0.7 \\
2.1 \\
5.1\end{array}$ & $\begin{array}{l}359.8 \\
410.1 \\
584.8\end{array}$ & $\begin{array}{l}60.3 \\
54.5 \\
54.4\end{array}$ \\
\hline Inactive & $\begin{array}{l}1960 \\
1970 \\
1980\end{array}$ & $\begin{array}{r}33.6 \\
75.7 \\
164.1\end{array}$ & $\begin{array}{r}5.6 \\
10.1 \\
15.3\end{array}$ & $\begin{array}{r}198.7 \\
251.3 \\
271.3\end{array}$ & $\begin{array}{l}33.3 \\
33-4 \\
25.3\end{array}$ \\
\hline
\end{tabular}

Source: National Statistical Institute (INE). For I960 and 1970: national population and housing censuses. For 1980: National employment survey. 
incomes) the secondary work force, mainly young people and women, tends to join the labour markets. In conditions of stability and economic prosperity it reverts to inactivity. Cáceres adds that this situation occurs predominantly in the bottom strata, while the secondary labour force of the top strata (especially women) tends, in contrast, to withdraw from work activity in periods of crisis. In the bottom urban strata, however, unemployment of the head of the household or reduction of the family income prompt young people and women to seek work.

The majority of these studies suppose that the oscillations in the participation rates correspond merely to short-term cycles of expansion or recession within a general downward trend caused mainly by the expansion of education. Careful analysis of the data from censuses and national household surveys on work activity and school attendance indicates, however, that in the past decade there has been a change of structure, and with it new trends in the distribution of young people by work activity and school attendance (table 1).

The main point about the change in the trends over the past decade is the clear relative decline in young people who do not attend school and are inactive, which indicates an accelerated incorporation in activity (usually not accompanied by effective employment). When the effective distribution of young people by activity and attendance in 1980 is compared with the distribution which would have been produced if the trends of the previous decade had been maintained, it can be concluded, firstly, that the "real" decline in inactivity is the most important change that has occurred, and that it can be estimated at 212800 persons. Secondly, that the increase in attendance is noticeably slower than the increase in activity. Thirdly, that two-thirds of the additional increase in attendance is attributable to the increase in the group of active attenders, and finally that twothirds of the reduction in the group of inactive persons who do not attend school is attributable to their assumption of activity without school attendance (table 2).

These characteristics are typical of periods of economic crisis, when there is a mass assumption of activity by the so-called "secondary labour force". In this case the group which provides the most newly active persons is made up mainly of women aged 15 to 19 from the lowest educational levels. However, there is also some doubt about the truly "secondary" nature of this young labour force. The year of reference (1980) cannot be considered typical of a short-term recession: on the contrary, according to official estimates, in the period 1976-1980 the product grew at rates above or close to $8 \%$ a year, and only two years later a sharp recessionary cycle began. There is much more justification for a hypothesis which associates such trends with a style of growth which, even in its best moments, maintained unemployment at double the historical rates and the real wages of the employed labour force at significantly lower levels than those of the previous decade. Since for a long time heads of household have been faced with unemployment or low wages, a reversal has begun in the downward trend of the participation rates, starting with the "weakest link" in the household: those members whose assumption of activity means lower short- and long-term costs ("inactive/not attending"). This assumption of activity can undergo small or even substantial changes in step with economic cycles, but it is determined mainly by the general economic framework in which these changes occur and, in particular, by the permanent level of opportunities of work and income which this framework offers the heads of households of the less-favoured strata of society.

Table 2

\section{CHILE: DIFFERENCES IN THE HISTORICAL TRENDS OF ECONOMIC ACTIVITY AND SCHOOL ATTENDANCE OF YOUNG PEOPLE, 1980}

Thousands of young people aged 15 to 24

Attending Not attending

$\begin{array}{lrr}\text { Active } & 51.2 & 161.6\end{array}$

Inactive $\quad 22.0 \quad-234.8$

Source: Calculations on the basis of data from the National Statistical Institute (INE): national population and housing censuses, I960 and 1970, and regional employment survey, 1980. 


\section{Occupational exclusion}

The greatest inconsistency of the promise of modernization has occurred, without doubt, in the area of employment. The conjunction of an increasing incorporation of youth groups in economic activity (despite the continued expansion of education) with the inability of the economy to generate, and even maintain, certain historical levels of employment produced a phenomenon of acute occupational exclusion which had a particularly severe effect on the new generations. Waged or established job opportunities declined sharply, as did the proportion and number of young people who managed to find work.

Exclusion is different from occupational "marginality" as described in the 1960s: marginality has a very different starting point, for it generally concerns migrants from the countryside with little schooling who have not become integrated in the urban world. The term "exclusion" refers, in contrast, to the state of occupational marginality which affects a large contingent of population which formerly had access to established urban jobs, or was acquiring such access, and moreover was mobilized socially and culturally in that direction. It thus describes the process of reversal both in the employment structure in the past decade and in the processes of social integration which had begun earlier. Exclusion must also be distinguished from mere statistical unemployment. Occupational exclusion does not arise exclusively either from changes in the labour supply (demographic pressure or incorporation of the secondary labour force in periods of crisis) or from conditions of recession, although both these factors must be taken into account. It has its origin in changes in the structure of employment (industrial crisis, reduction of public employment, etc.) and, therefore, in the patterns of development which reduce and impair the economy's capacity to generate established jobs: it is a question of the structural processes which establish and increase the mass of unemployed, underemployed and poor urban dwellers.
The origin of the occupational exclusion of young people lies mainly in the decline in manual work, in particular in manufacturing industry. In the past decade the contribution of industry to the product and to employment fell visibly as a result of the policies of external openness and liberalization of the labour market. There was a collapse in the support of the former processes of modernization and the exports-substitution industry based on State backing and protection, with alarming consequences for employment.

This situation can be seen in table 3. The proportion of workers -waged manual

Table 3

CHILE: RELATIVE PROPORTION OF NONAGRICULTURAL MANUAL JOBS AND INDUSTRIAL MANUAL JOBS IN YOUTH GROUPS AND IN THE TOTAL EMPLOYED EAP, 1971, 1980, 1982

\begin{tabular}{lccc}
\hline & Years & $\begin{array}{c}\text { Young } \\
\text { people } \\
(15-24)\end{array}$ & Total \\
\cline { 2 - 4 } $\begin{array}{l}\text { Manual workers in } \\
\text { total of employed }\end{array}$ & 1971 & 37.3 & 31.2 \\
persons & 1980 & 26.3 & 22.7 \\
& 1982 & 17.5 & 19.1 \\
Productive sector & & & \\
manual workers in & & & \\
total of employed & 1971 & 27.0 & 23.1 \\
persons & 1980 & 14.6 & 14.2 \\
& 1982 & 9.5 & 10.7 \\
Productive sector & & & \\
manual workers in & & & \\
total of manual & 1971 & 72.6 & 74.0 \\
workers & 1980 & 55.6 & 62.8 \\
& 1982 & 54.3 & 56.2 \\
$\begin{array}{l}\text { Industrial manual } \\
\text { workers in total } \\
\text { of manual workers }\end{array}$ & 1971 & 56.3 & 50.5 \\
& 1980 & 38.6 & 40.6 \\
& 1982 & 35.8 & 39.2 \\
\hline
\end{tabular}

Source: Martinez and León, (1984). 
workers - fell sharply throughout the decade: at the beginning of the decade some $40 \%$ of employed young people were manual workers. In 1980 only one-quarter of them were still manual workers, and that proportion declined even more in the subsequent years of crisis. The proportion of manual workers in the total of occupied persons had thus taken a dizzying plunge. The decline in manual work was especially significant in the productive sectors (industry, construction, transport and mining). At the end of the decade the number of young manual workers in productive sectors had fallen to half of the figure for the decade's beginning (barely $15 \%$ of employed persons in 1980, as against $27 \%$ in 1971). At the same time there was a change in the internal composition of manual employment: it became tertiarized and this meant deteriorations in working conditions, income levels, stability and the opportunities for young people to join trade unions. Moreover, the reduction in productive manual employment was concentrated in manufacturing industry. Whereas earlier manual employment was basically industrial (about $60 \%$ of manual workers were in industry), the proportion of industrial workers in manual employment at the end of the decade had fallen to below $40 \%$. Lastly, the numerical superiority of young manual workers also disappeared, especially in the productive sectors; there occurred an ageing of the working population, an unmistakable sign of the difficulties encountered by young people in finding work in this sector.

Additional information about these processes is given in table 4, which indicates the numbers and participation of manual workers in the young non-agricultural economically active population. These data show in greater detail the magnitude of the reduction in productive manual jobs and the influence of the industrial depression on that reduction.

As we see, industrial manual workers accounted for $24 \%$ of the young non-agricultural EAP in 1971 (approximately 140000 young workers in industry). In 1980 this proportion had fallen to only $9.5 \%$ (some 75000 industrial workers). These declines occurred in traditional

Table 4

\section{CHILE: PROPORTION OF MANUAL WORKERS AND CRAFTSMEN IN THE NON- AGRICULTURAL YOUNG EAP (AGED 15-24), 1971, 1980, 1982}

\begin{tabular}{|c|c|c|c|c|c|c|}
\hline & & 971 & & 980 & & 982 \\
\hline & $\begin{array}{c}\text { Per- } \\
\text { centages }\end{array}$ & $\begin{array}{l}\text { Thousands } \\
\text { of persons }\end{array}$ & $\begin{array}{c}\text { Per- } \\
\text { centages }\end{array}$ & $\begin{array}{l}\text { Thousands } \\
\text { of persons }\end{array}$ & $\begin{array}{c}\text { Per- } \\
\text { centages }\end{array}$ & $\begin{array}{l}\text { Thousands } \\
\text { of persons }\end{array}$ \\
\hline Traditional industrial workers & 14.7 & 84.4 & 6.2 & $49-7$ & 4.1 & 33.7 \\
\hline Modern industrial workers & 9.2 & 52.9 & 2.8 & 21.9 & 1.4 & 11.1 \\
\hline $\begin{array}{l}\text { Strategic sector workers } \\
\text { (excluding copper) }\end{array}$ & 0.5 & 2.8 & 0.5 & 4.1 & 0.1 & 1,0 \\
\hline Construction workers & 5.5 & 31.5 & 3.1 & 24.4 & 1.6 & 13.1 \\
\hline Waged workers in mining & 1.0 & 6.2 & 1.0 & 8.1 & 0.4 & 3.2 \\
\hline Waged workers in transport & 5.0 & 29.1 & 2.6 & 21.0 & 1.6 & 13.2 \\
\hline Productive sector workers & 35.9 & 206.9 & 16.2 & 129.2 & 9.2 & 75.3 \\
\hline Trade and services workers & 11.7 & 67.5 & 13.9 & 110.8 & 10.5 & 86.5 \\
\hline Craftsmen & 4.7 & 27.0 & 4.1 & 32.5 & 2.9 & 24.2 \\
\hline $\begin{array}{l}\text { Total manual workers } \\
\text { and craftsmen }\end{array}$ & 52.3 & 301.4 & 34.2 & 272.5 & 22.6 & 186.0 \\
\hline $\begin{array}{l}\text { Total non-agricultural } \\
\text { EAP }(15-24)\end{array}$ & 100.0 & 575.6 & 100.0 & 798.5 & 100.0 & 822.5 \\
\hline
\end{tabular}

Source: Martínez and León (1984), on the basis of INE figures. 
industry (foodstuffs, beverages, tobacco, textiles, clothing, etc.) and, above all, in modern substitution industry (timber, chemical products, rubber and plastic, cement, etc.). In both sectors young manual workers were found in industry. Manual jobs were maintained only in strategic industries and mining, but in both they represented a very insignificant proportion of the young proletariat. The crisis was concentrated in the substitution industry, which in the space of a decade shed some 65000 jobs previously held by young people. There were also declines in the sectors of construction (despite the fact that at the end of the decade this sector experienced a favourable period) and transport, which together represented a reduction of approximately 15000 productive jobs.

The expansion of manual activities in the tertiary sector does not succeed in countering the sharp decline in industrial employment. The increases in manual workers in trade and services and in the crafts are insufficient to compensate for the decline in productive manual jobs. Manual workers in the non-productive sectors increase their share in young nonagricultural EAP from $11.7 \%$ to $13.9 \%$, while craftsmen decline from $4.7 \%$ to $4.1 \%$ between the beginning and end of the decade. Craft jobs, moreover, had always been occupied mainly by adults, owing to the skills and capital required; they therefore represent a very difficult employment alternative for young people excluded from industry.

The crisis in manual employment had a clear effect on the increase in "excluded" young people -defined as those who remain unemployed, or in government mínimum employment programmes, or in domestic service, or own-account workers in marginal trade and services. These doubled their share in young non-agricultural EAP from $23.3 \%$ to $45.5 \%$ between 1971 and 1980 - an absolute increase of 230000 young people. The decade of the 1970s closed, in fact, with 363000 excluded young people, and it had begun with only 134400 .

First among the traditional categories of occupational marginality is domestic employment, which has tended to stabilize in the past decade: its relative weight is maintained at approximately $11 \%$ of the young EAP, although in absolute terms this means an increase of almost 23000 persons.

Here it is important to note the development of domestic employment, which historically had shown a sustained reduction in its share of the young EAP. The figures of the University of Chile indicate that between I960 and 1970 domestic service declined from $27.9 \%$ to $21.9 \%$ in the $15-19$ age group and from $20.2 \%$ to $15 \%$ in the $20-24$ age group. In the past decade, in contrast, the proportion of domestic servants practically stabilized itself, with rates of $20.7 \%$ and $13-2 \%$ respectively in the two age groups. A study by Heskia (1980) calculates the proportion of domestic employment in the employed young EAP for the period 1957-1979. According to her figures, throughout this period female domestic servants accounted for an average of $26 \%$ of female jobs in the 14-19 age group and approximately $15 \%$ in the $20-25$ age group. Heskia's series indicates a decline (not always continuous) in the proportion of female domestic servants in the two groups, which reaches its lowest point in 1974 with proportions of $131 \%$ and $4.7 \%$ respectively, and then climbs from the 1975 crisis to reach, in the remaining years, the level of the historical average indicated above. Rosales reaches a similar conclusion.

The reduction in domestic employment has been explained by a decline in work activity on the part of young women and by the extension of schooling and the higher level of education which these women enjoy. As has been pointed out, the crisis pushes up the rate of participation of young women from the low strata, who again enter domestic service. The lack of diversification of female employment in these strata - accentuated by the reduction in the proportion of female manual workers, also detected by Rosales - feeds this trend in female employment.

With respect to the remaining categories of occupational marginality, mention must be made of the increase in "marginal traders" who grow from $2.3 \%$ to $3.1 \%$ in the period (more than 10000 young people engage in this activity). The proliferation of street traders is a characteristic of the employment crisis, especially in the big towns. Much more 
important, however, is the institution of the PEM (Programa de Empleo Mínimo - Minimum Employment Programme) which covered almost 50000 young people in 1980 and accounted for $12.9 \%$ of the young EAP. The PEM was set up during the 1975 crisis as a way of absorbing the effects of the generalized unemployment. The programme was maintained after the crisis, however, fluctuating between 120000 and 180000 persons (until it was again expanded in the present recession) and it took in an increasing number of jobless young people and women. In 1980 young people made up $54.9 \%$ of the programme.

In all marginal jobs at present account for less than half of occupational exclusion. Whereas in 1971 one-third of excluded persons were unemployed, in 1980 unemployment affected some $534 \%$ of them. In the past decade the number of unemployed has tripled: from 48100 to 193800 young people, and from $8.3 \%$ to $24.3 \%$ of the young EAP (table 5). Open unemployment has thus been the predominant form taken by the jobs crisis in these years.

In the last quarter of a century the development of this phenomenon has been fairly clear. Three phases are usually distinguished. The phase of the 1960s was characterized by relatively low unemployment rates; the period 1970-1973 was marked by large-scale jobs policies which brought unemployment down to its historically lowest levels; and the last phase produced an explosive increase in unemployment, even outstripping the periods of recession. The evolution of employment among young people follows this same trajectory, as can be seen from the graph, in accordance with the unemployment series for Greater Santiago produced by the University of Chile.

According to these data, unemployment shows an average of $36.7 \%$ in the 14-19 age group and $23.2 \%$ in the $20-24$ age group in the period 1974-1982, thus doubling the historical averages registered in previous years. Unemployment increases sharply in times of crisis, but it has never truly decreased; even in periods of economic "prosperity" open unemployment stayed at about $25 \%$ of the young labour force (always, of course, with different rates according to age). Even when the periods of crisis are not taken into account, some 200000 young people regularly remained out of work in those years.

These trends find their culmination in the recession currently affecting the Chilean

Table 5

CHILE: OCCUPATIONAL COMPOSITION OF EXCLUDED YOUTH, 1971, 1980, $1982^{\circ}$

\begin{tabular}{|c|c|c|c|c|c|c|}
\hline \multirow[b]{2}{*}{ Occupational stratum } & \multicolumn{2}{|c|}{1971} & \multicolumn{2}{|c|}{1980} & \multicolumn{2}{|c|}{1982} \\
\hline & $\begin{array}{l}\text { Thousands } \\
\text { of persons }\end{array}$ & $\begin{array}{c}\text { Per- } \\
\text { centages }\end{array}$ & $\begin{array}{l}\text { Thousands } \\
\text { of persons }\end{array}$ & $\begin{array}{c}\text { Per- } \\
\text { <centages }\end{array}$ & $\begin{array}{l}\text { Thousands } \\
\text { of persons }\end{array}$ & $\begin{array}{c}\text { Per- } \\
\text { centages }\end{array}$ \\
\hline Domestic employment & 66.5 & 49.5 & 89.1 & 24.5 & 70.05 & 14.5 \\
\hline $\begin{array}{l}\text { Marginal employment in } \\
\text { trade and services }\end{array}$ & 19.8 & 14.7 & 33.2 & 9.1 & 27.9 & 5.7 \\
\hline PEM-POJH* & & & 46.9 & 12.9 & 98.7 & 20.3 \\
\hline $\begin{array}{l}\text { Unemployed and first-time } \\
\text { job seekers }\end{array}$ & 48.1 & 35.8 & 193.8 & 53.4 & 288.6 & 59.4 \\
\hline Total excluded & 134.4 & 100.0 & 363.0 & 100.0 & 485.7 & 100.0 \\
\hline $\begin{array}{l}\text { Excluded young people in } \\
\text { non-agricultural EAP }\end{array}$ & & 23.3 & & 45.5 & & 59.1 \\
\hline
\end{tabular}

Source; Martinez and León (1984).

"Young people aged 15 to 24 .

*PEM: Programa de Empleo Mínimo (Minimum Employment Programme).

${ }^{c}$ POJH: Programa Ocupacional para Jefes de Hogar (Work Programme for Heads of Household). 
economy (table 5). Exclusion reaches alarming proportions: it increases from $45.5 \%$ of the young EAP in 1980 (363 000 young people, as we have seen) to 59-1\% in 1982 (485700 young people). At the same time, the reduction in manual and non-manual jobs reaches 100000 in the short space of two years: the employment figures are 432000 in 1980 (54.5\% of the young non-agricultural EAP) and 335400 in 1982 (only $41.9 \%$ ). The crisis can thus be seen as areal jobs disaster .suddenly striking approximately $25 \%$ of the young people who had found some employment in the already harsh conditions prevailing at the end of the decade.

The crisis causes a great reduction in the number of manual workers in productive sectors; among young people there is a spectacular reduction of $40.7 \%$ (among adults it is $29.9 \%$ ). In this case, the crisis affects manual employment in manufacturing industry (including the strategic sectors), -which is reduced to an insignificant level $(5.6 \%$ of the total EAP, i.e., 45000 young people), manual employment in construction (which in 1982 is only $1.6 \%$ of the EAP, i.e., 13000 young people), and manual employment in transport and mining. The productive sectors shed more than 50000 young manual workers (one half of total redundancies) and these sectors account for only $9.2 \%$ of the young EAP. Manual workers in nonproductive sectors and craftsmen also show declines, although not as pronounced as the previous ones, which confirms that the crisis severely depresses the "real" sector of the economy.

It is obvious that the crisis exacerbates exclusion. Here too the predominant form of exclusion is open unemployment (which affects almost $60 \%$ of the excluded young people and accounts for one half of total exclusion). Youth unemployment increases from 193800 to 288600 (i.e., from $24.3 \%$ in 1980 to $35.1 \%$ in 1982). However, on this occasion unemployment also has a serious effect on adults: in the over-24 EAP unemployment increases from 184600 to 430500 (from 8 to $18.2 \%$ between these years), and the participation of young people also declines (from $51.2 \%$ to $40.1 \%$ ). This means that, in real terms, the crisis has affected the adult world more severely. The magnitude of adult unemployment at a time when the PEM was absorbing large numbers of young people and women prompted the establishment of the POJH (Programa Ocupacional para Jefes de Hogar —Work Programme for Heads of Household - which

Figure 1

GREATER SANTIAGO: EVOLUTION OF THE UNEMPLOYMENT RATES OF YOUTH GROUPS AND TOTAL LABOUR FORCE, 1960-1982

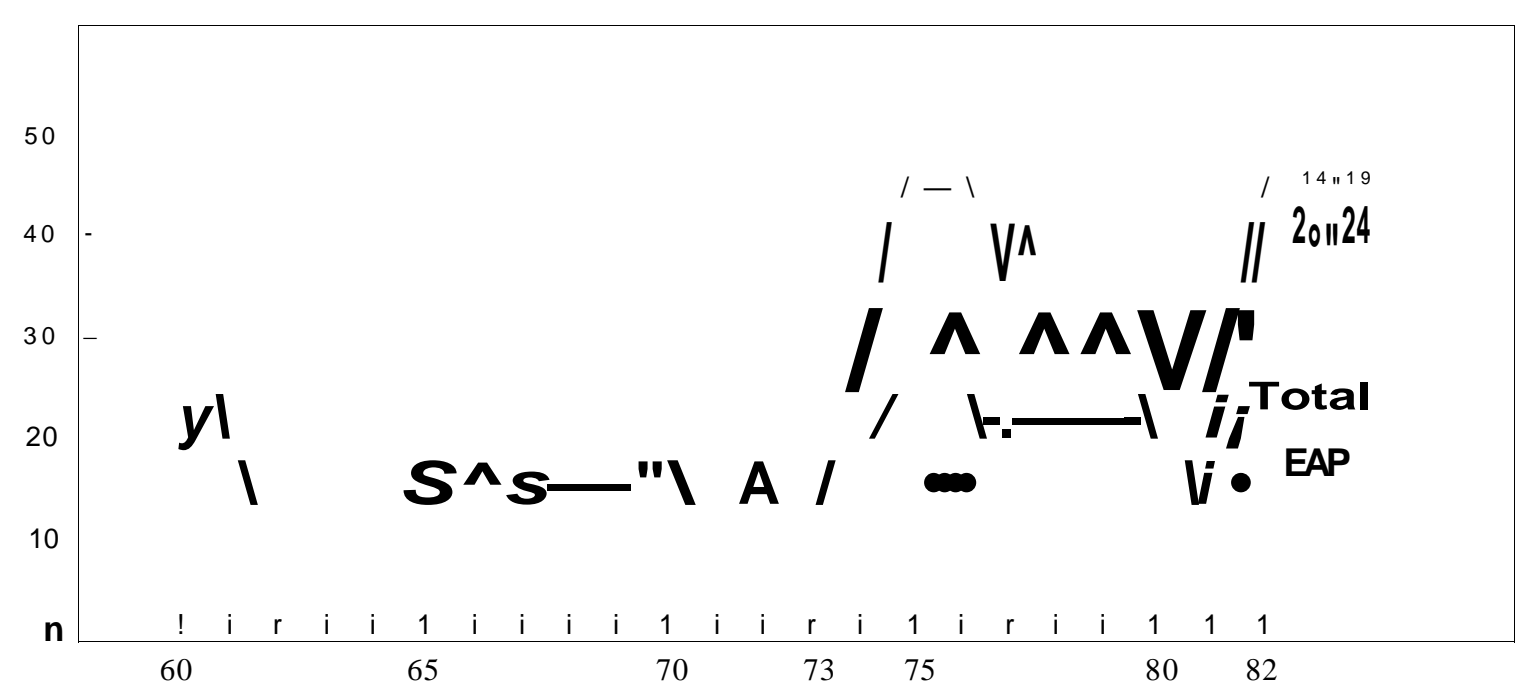

Source: Employment and unemployment survey by the University of Chile (June of each year). 
was inaugurated with a subsidy which doubled the PEM) in October 1982; this is not reflected in the figures of the National Statistical Institute. Between 1980 and 1982 the participation of young people in the PEM continued to increase, reaching approximately $40 \%$ of the programme in the latter year; it had doubled from 46900 to 98700 young people.

It can thus be said, in general terms, that the evolution of employment among young people has followed a sharp incline: during the 1960 s the expansion of schooling was accompanied by occupational mobility expressed notably in the reduction of the "excluded", i.e., in low unemployment rates and a reduction in marginal jobs, as well as in the vitality of manual employment and the expansion of middle-range waged employment. Social modernization based on industry and the State collapsed in the following decade; this was brought about by the demographic pressure of youth groups on the work markets, by the slowdown in the decline in the participation rates (despite the increase in the supply of education) and, above all, by the marked process of de-industrialization. All these factors, operating in acute recessions, applied the brakes sharply to the modernization process. Exclusion subsequently increased, especially in the form of open unemployment and underemployment, but also in the interruption in the decline of marginal jobs; the employment of young people was confined essentially to a segment which had managed to complete its schooling, and sometimes obtain higher education and could secure middle-range employment in the tertiary sector. This sector is probably the only area in which there are still some traces of the modernization process which enthused Chilean society a quarter of a century ago. The present crisis is the culmination of this process of exclusion and it has affected young Chileans in particular.

\section{Other dimensions of exclusion}

Employment problems are not the only manifestation of exclusion. Mention must also be made in this connection of the processes which have affected the working-class family and of the exclusion from housing experienced by young people from that class. Observations made on the basis of a recent survey (Valenzuela, 1984) indicate that the nuclearization of the working-class family has come to a standstill or gone into reverse: extended families are reappearing and the size of households is increasing, because young people cannot set up independent households (table 6). These observations indicate in fact that the average number of persons per household is now 6.6, as against 5.6 twenty years ago according to DESAL figures; the proportion of extended families is in excess of $50 \%$ of the households interviewed, and in these households the commonest arrangement is for married children to be accommodated in their parents' homes. In the sample, $54.2 \%$ of the young married couples live with their parents or parents-in-law, and a further $20.6 \%$ have joint occupancy (sharing accommodation but not incomes with another household).

This inability of young people to obtain their own housing and thus organize stable families stems both from the free-market policies which substantially reduced the construction of low-cost housing and from the employment crisis described above, which prevents them from securing stable incomes sufficient for the establishment of new households. The annual average of housing starts declined from 52000 units in 1971-1973 (in the previous five-year period it was about $40000)$ to 30000 units in 1973-1982. In addition, the proportion of housing starts in the public sector, which was formerly above $50 \%$, declined to $19-5 \%$ in the latter period. The upward trend in housing construction was 
Table 6

\section{SANTIAGO: FAMILY STRUCTURE IN THE WORKING-CLASS STRATUM BY HOUSING TYPE AND LOCATION}

Nuclear simple

Nuclear with young married

Nuclear joint occup.

Extended w/ other relative

Extended w/ cousins

Extended w/ married siblings

Extended w/ young married

Extended w/ both

Extended w/ other married couple

\begin{tabular}{rrrrrrr}
\hline & Districts & & Three- & \multicolumn{2}{c}{ Young people } \\
\cline { 1 - 1 } \cline { 5 - 6 } $\begin{array}{c}\text { San } \\
\text { Gregorio }\end{array}$ & $\begin{array}{c}\text { Lo } \\
\text { Hermida }\end{array}$ & $\begin{array}{c}\text { Herminda } \\
\text { de la } \\
\text { Victoria }\end{array}$ & $\begin{array}{c}\text { district } \\
\text { average }\end{array}$ & Single & Married \\
\hline 33.3 & 44.6 & 33.0 & 37.2 & 46.8 & - \\
1.4 & 6.9 & 5.8 & 4.7 & - & 24.2 \\
6.1 & 8.9 & 13.1 & $9-8$ & 7.1 & 20.0 \\
9.5 & 8.9 & 11.8 & 10.2 & 13.0 & - \\
10.9 & 2.5 & 11.8 & 8.2 & 10.3 & - \\
25.2 & 14.9 & 7.7 & 14.7 & 17.7 & - \\
6.8 & 6.4 & 10.0 & 7.9 & - & 35.0 \\
4.1 & 3.0 & 3.2 & 3.3 & - & 19.2 \\
2.7 & 4.0 & 4.5 & 3.9 & 5.3 & 1.6 \\
\hline
\end{tabular}

Source: Valenzuela, (1984).

interrupted in the latter years, and most building starts were in the private sector, which produced in accordance with market demands. It is estimated that the housing deficit may have increased by 300000 units in the past decade, so that the total deficit would be in the order of 850000 dwellings (Rodriguez, 1984).

These restrictions on access to low-cost housing explain the cohabitation of families in already precarious households. This causes enormous upsets: in general terms, family cohesion and the stability of young marriages are weakened. It has also been suggested that the housing deficit is connected with the increase in the numbers of young unmarried mothers and abortions. However that may be, the pressure for housing has increased strongly; it is calculated that between 135000 and 200000 families live in joint occupancies in Santiago, which represents a suppressed demand for building sites in the order of 4000 to 6000 hectares. The magnitude of the land-seizure movements is evidence of the size of this demand.

Exclusion from employment and exclusion from housing are classical symptoms of urban marginality. In both cases, as has been pointed out, these kinds of exclusion primarily affect young people. It is important to add, however, that working class youth is largely excluded from participation. The survey mentioned above indicates that some $70 \%$ of young people lack organized activities, except in sports clubs (which attract mainly men). The rate of tradeunion membership is virtually nil $(1.1 \%)$, as is participation in neighbourhood organizations $(0.5 \%)$. The organization indices for young people are held up only by their participation in religious organizations ( $11 \%$ of young people) and in parochial groups $(10.8 \%)$ (table 7$)$.

Table 7

SANTIAGO: LEVEL OF SOCIAL ORGANIZATION AMONG YOUNG PEOPLE IN THE WORKINGCLASS STRATUM

\begin{tabular}{lrrrr}
\hline & $\begin{array}{c}\text { Not } \\
\text { organ- } \\
\text { ized }\end{array}$ & $\begin{array}{c}\text { Poor } \\
\text { organi- } \\
\text { zation" }\end{array}$ & $\begin{array}{c}\text { Average } \\
\text { organi- } \\
\text { zation }\end{array}$ & $\begin{array}{c}\text { Good } \\
\text { organi- } \\
\text { za tion }^{\text {c }}\end{array}$ \\
\cline { 2 - 5 } Districts & & & & \\
San Gregorio & 45.6 & 36.1 & 8.8 & 9.5 \\
Lo Hermida & 38.6 & 38.1 & 16.3 & 6.9 \\
Pudahuel & 44.8 & 25.8 & 12.7 & 16.7 \\
\hline
\end{tabular}

Source: Valenzuela, (1984).

"Includes sports clubs.

"Includes neighborhood organizations, trade unions, cultural and youth centres.

'Includes Christian communities. 
Political and corporative participation is ruled out by political authoritarianism and unemployment, and it is only partially offset by community participation through the churches, which have been one of the main refuges in the crisis.

In short, the involvement of young people in the world oí social institutions is limited to the school Apart from this, they are completely cut off from organized society and especially from the State, which - in the circumstances which we have described - seems to them to be an almost exclusively penal instrument.

\section{Differences among an excluded youth}

It is sufficiently well established that age differences used not to have great importance in the lower strata of the population, given the early entry into work and marriage. But the expansion of education in recent decades began to give strength to the traditional concept of youth as "a period of transition". Paradoxically, this educational effect has led in recent years to exclusion from employment and housing, which has prolonged the "age of youth" in the lower strata. The generalized unemployment and underemployment affecting young people and the difficulties they encounter in setting up their own households are processes which delay their entry into the adult world. The notion of "youth" in this sense is also encouraged by the almost exclusively urban origins of the new generations (unlike the earlier generations of migrants) and by the exposure of young people to urban mass culture. The expansion of education, the impossibility of securing economic independence and a separate home, the urban origins and the numbers and concentration of young people in the same situation are all factors which gather excluded young people into a separate social group within the world or urban marginality.

In these conditions of exclusion and alienation urban working-class youth shows the characteristics of disordered behaviour, with little apparent cultural cohesion, which have been associated with the breakdown of standards (Valenzuela, 1984). All the processes which contribute to the formation of marginal youth groups tend in this direction: work alienation and instability, fragmentation and breakdown of family cohesion, political exclusion and social disorganization. All the processes of exclusion from organized society (the world of social institutions) have been at the same time processes of disintegration of collective life and solidarity.

These non-organized young people show symptoms of withdrawal (drugs) and rebellion (revolt) which are consistent with a more serious breakdown of standards. In contrast, among organized young people (usually in Christian organizations) the symptoms of refuge and radical mobilization indicate the way to reduce this breakdown of standards. The symptoms of withdrawal and refuge prevail in periods of economic stability among nonorganized and organized young people respectively; the symptoms of rebellion and mobilization occur in periods of crisis, also for each group respectively. The first case is dominated by the many forms of reaction and defence against marginality; in the second case, possibilities arise for widespread social confrontation. In the period preceding the crisis, in fact, young people from the working-class strata exhibited two clear characteristics: the spread of the use of drugs and the emergence of grassroots working-class Catholic movements.

Drug use has been associated mainly with the search for immediate pleasure (Lailhacar, 1982). This includes behaviour connected with eroticism, music and recreation. 
Experimentation with drugs, in fact, has an almost exclusively escapist purpose: immediate gratification and sense of disassociation which provide a respite, even if only a fleeting one, from the realities of space and time, and an escape from the hardships of life. Drug use is not a culturally unifying experience, nor is it a community activity. The hippie aspect of drug use has disappeared. The sexual conduct of marginal young people characterized by lack of inhibitions and prejudices and by a basic instability is another aspect of this kind of search for immediate pleasure.

On the other hand, a reaction against this disintegration (and the spread of disordered behaviour) has emerged in the community refuge. Some authors have argued that the flourishing of grassroots church organizations in working-class areas has indeed been a response to the fragmentation effects of the market and State exclusion. A connection with the old Pentecostal movements has also been established, and it is pointed out that these organizations act in exactly the same way as the pentecostal communities described by Lalive (1969) in Chile: "they reduce social rootlessness by restoring the primary group, formed around a network of affective relationships and shared values". Pentecostalism was, in fact, the counterpart of the model of working-class integration. "The expansion of pentecostalism is concurrent with the period of internal migrations (roughly the decade of the 1930s) which also coincides with the decline of rural society and the beginnings of industrialization. This typical phenomenon of transition causes dislocations among the working masses. Lalive discovers, moreover, that pentecostalism takes root precisely in the marginal categories of a society in flux, in the urban peripheries and the rural frontier zones where the property structure breaks down most sharply. In general terms, while socialism grows as a working-class ideology, pentecostalism develops among the uprooted marginal masses (who take refuge in a traditional value system and cut themselves off culturally from urban society)" (Valenzuela 1984).

Although the grassroots church organizations propound a different theology from that of the traditional pentecostal communities, they are still expressing a reaction against a similar situation: the termination of the working-class mode or model of integration (waged work, trade-unionism, access to political representation in the State). In these circumstances both church and pentecostal grassroots organizations reestablish a community ideology (mutual help, co-operation, solidarity, human rights) and they invoke, lastly, the need to restore collective solidarity and dignity.

The crisis has created a new situation in which urban working-class youth has an important role to play. Given the closing-off of the normal channels of social integration, as well as the channels of political expression and opinion, urban working-class young people, severely stricken by the effects of the crisis take up a kind of social action unforeseen either in the political organization of the State or by the political groupings which oppose that organization. This emerges as urban protest, which takes the place of protest at the place of work or study. This kind of protest can be described as "disordered rebellion". On the one hand, it is not connected with political institutions or groupings, for it does not seem to be concerned with claims for restitution; on the other hand, given the closing-off of the channels of participation, it creates extremely aggressive forms of struggle.

There is no doubt that the political radicalism of marginal youth stems from the conditions described and it raises new questions about the future of this generation. 


\section{Bibliography}

Cáceres, Carlos ( 1981 ) : Participación laboral y desocupación, según estratos de ingresos. Gran Santiago, 1957197ft. Degree thesis, Faculty of Economics and Administrative Science, University of Chile.

DESAL (Centro para el Desarrollo Económico y Social de América Latina) (1970): La marginaiidad urbana: origen, proceso y modo. Resultados de una encuesta en poblaciones marginales del Gran Santiago. Buenos Aires: Editorial Troquel.

Heskia, Isabel (1980): Distribución del ingreso en el Gran Santiago, 1957-1978. Research paper. Economics Department, University of Chile.

Lailhacar, R. and others (1982): Juventud, drogas y neoprén. Santiago, Chile: Editorial Leu.

Lalive, Cristian (1968): El refugio de las masas. Estudio sociológico del pentecostalismo chileno. Santiago, Chile: Editorial del Pacífico.

Martinez, Javier and Eugenio Tironi (1985): Est ratificado» y cambio social en Chile en la década del setenta. (E/CEPAL/R.M9). Santiago, Chile: ECI.AC

Martínez, Javier and Arturo León (1984): La involución del proceso de desarrollo y la estructura social. Working paper. Santiago, Chile: Centre for Development Studies (CED).

Rodríguez, Alfredo ( 1984): Poruña ciudad democrática. G>leccjón Estudios Sociales. Santiago, Chile: Ediciones Sur.

Rosales, Osvaldo (1979): La mujer chilena en la fuerza de trabajo: participación, empleo y desempleo (1957-1977). ESCOI.ATINA thesis, University of Chile.

Vaienzueia, Eduardo (1984): La rebelión de los jóvenes. G>leccjón Estudios Sociales. Santiago, Chile: Ediciones Sur. 